and biotic proxies. These studies suggest that different organisms (e.g. plants, cladocera, chironomidae) responded very fast to climate change during the Late Glacial and the Holocene (i.e. within 0-20 years). In the case of the Holocene study, vegetational responses to climate change were highly complex and related to physiological characteristics and life histories of the species involved. The resulting interspecific competition patterns were so complex that the response signal was not recognized as climatically driven in numerous previous studies, although it occurred on a subcontinental scale.
We conclude that because of the complex orographic situation and the resulting highly differentiated biome belts in the Alps, high temporal and spatial precision and resolution are required to provide a clear understanding of past climate changes and ecosystem responses. Such high resolution studies are also essential to overcome seeming differences between modern ecological and paleoecological paradigms of ecosystem functioning.

\section{ACKNOWLedgements}

Improvements of the manuscript by Herbert E. Wright Jr. are gratefully acknowledged.

\section{REFERENCES}

Haas, J.N., Richoz, I., Tinner, W. and Wick, L., 1998: Synchronous Holocene climatic oscillations recorded on the Swiss Plateau and at timberline in the Alps. The Holocene, 8: 301-309.

Magny, M. and Richoz, I., 1998: Holocene lake-level fluctuations in Lake Seedorf, southern Swiss Plateau. Eclogae geol. Helv., 91: 345-357.

Maisch, M., Wipf, A., Denneler, B., Battaglia, J. and Benz, C., 1999: Die Gletscher der Schweizer Alpen. Gletscherhochstand 1850, Aktuelle Vergletscherung, Gletscherschwund-Szenarien. vdf, Zürich, 373 pp.

Tinner, W., Ammann, B. and Germann, P., 1996: Treeline fluctuations recorded for 12,500 years by soil profiles, pollen, and plant macrofossils in the central Swiss Alps. Arctic and Alpine Research, 28(2): 131-147.

For full references please consult:

www.pages-igbp.org/products/newsletter/ref20013.html

\title{
Paleoenvironmental Reconstructions for Mountains in the Eurasian Mid-Continent
}

\footnotetext{
*Tatiana Blyakharchuk1, Ivanka Stefanova2, Herbert E. Wright3 and Brigitta Ammann4

1 Scientific Research Institute of Biology and Biophysics, Tomsk State University, 634050Tomsk, Russia, ta@pochta.tomsk.ru 2 Institute of Botany, Academy of Sciences, Sofia, Bulgaria, Current Address: Park Street, New Haven, USA, vanja_stefanova@yahoo.com 3 Limnological Research Center, University of Minnesota, Minneapolis MN 55455 USA, hew@maroon.tc.umn.edu

4 Institute of Plant Sciences, University of Bern, Switzerland, brigitta.ammann@ips.unibe.ch
}

Paleoenvironmental reconstructions for the Pirin Mountains (southwestern Bulgaria) and the Altai Mountains (southern Siberia, Fig.1) provide insight into the relationships between long-term vegetation dynamics and orbital forcing at two high-elevation sites in the Eurasian mid-continent. The topography of mountain regions constrains vegetation into distinct altitudinal bands, and these bands are sensitive to changes in both temperature and effective moisture through time. The sequence of late-glacial and early-Holocene vegetational change and the vertical displacement of vegetational bands are reconstructed for these mountains by pollen analyses at multiple sites along altitudinal gradients. However, the complexities associated with the dry early-Holocene conditions at these mid-continent sites require additional studies in order to disentangle the various responses of taxa to long-term regional climatic changes.

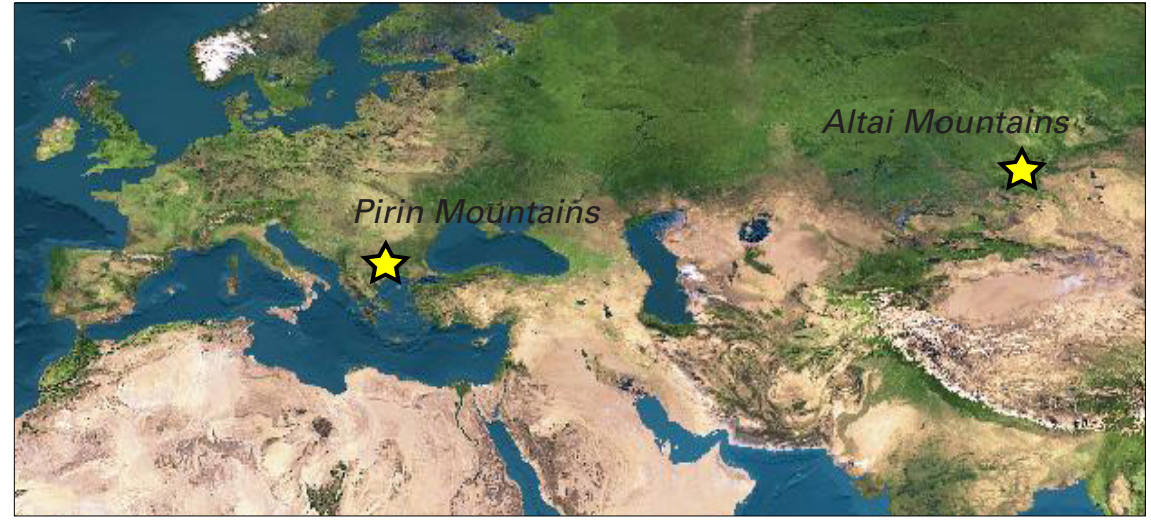

Fig. 1: Location of the two case-study areas in the Eurasian mid-continent

\section{Long-term vegetation dynamics in the Pirin Mountains, Bulgaria}

The Pirin Mountains are situated in the eastern part of the Balkan Peninsula. The climate is more continental and significantly drier than in the Alps. Temperate deciduous trees occur at low elevation, followed by beech and then various conifers extending up to the tree line at about 2,200 m. Of particular biogeographic interest in the Pirin Mountains is the common occurrence of the Balkan endemic Pinus peuce and (on calcareous soils) the Balkan sub-endemic Pinus heldreichii.

Pollen analysis of lake sediments, recovered from several sites near tree line, reveals an unusual sequence of changes in forest composition. After a late-glacial sequence dating back to $13,000{ }^{14} \mathrm{C}-\mathrm{yr}$ BP at lake Kremensko, the early-Holocene tree line was formed by birch which did not reach as high as the modern tree line (Fig. 2). At Dalgoto Lake close to modern tree line, the early-Holocene pollen assemblage of oak, elm, linden and

\footnotetext{
* The investigations in the Pirin Mountains were undertaken by Ivanka Stefanova, and those in the Altai Mountains by Tatiana Bliakhartchouk. H.E. Wright and Brigitta Ammann participated in the field work and aided in the interpretation of the pollen stratigraphy in both areas.
} 


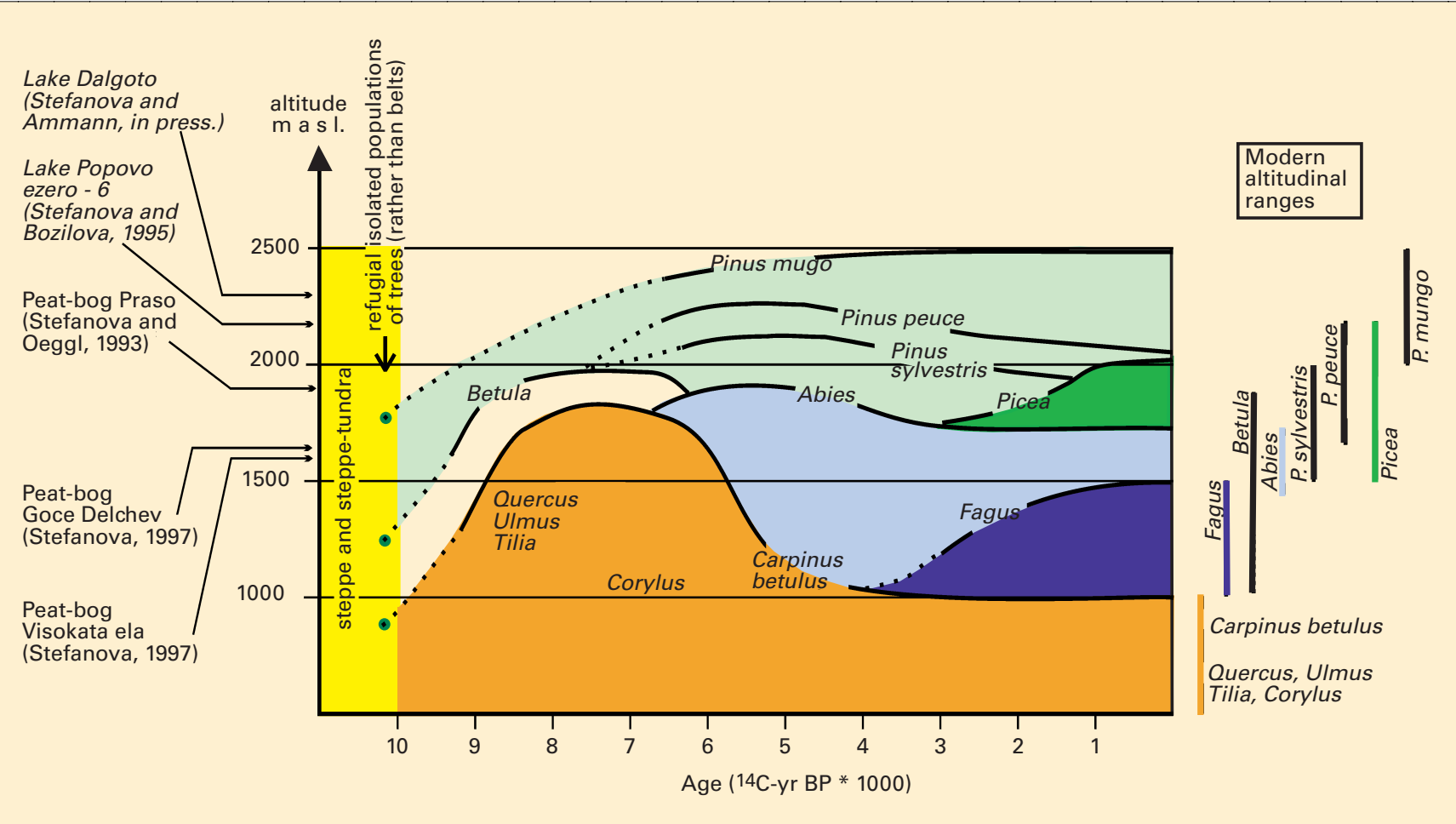

Fig. 2: Altitude-time diagram for the Holocene forest belts in the Pirin Mountains, showing for the early Holocene the high altitudinal range of deciduous forest and the low treeline, followed in the mid-Holocene by the immigration and expansion of conifers, resulting in a depression of the deciduous forest and the increased elevation of the treeline. The belts are simplified, and only the upper limits of tree species or genera are shown. Within the belts taxa may mix, e.g. spruce and fir in the belt marked in blue. At the sites Lake Popovo, Praso and Goce Delchev the analysis of plant macrofossils helped to distinguish between presence and absence of tree genera. (Adapted from Stefanova and Ammann, in press.).

hazel is attributed entirely to transport of pollen from lower-elevation forests to above the forest limit, where the treeless landscape had low pollen production (Stefanova and Ammann, in press). However, oak macrofossils at sites as much as $800 \mathrm{~m}$ above the present range of oak clearly demonstrates that the temperate forest reached higher elevations during the early Holocene, perhaps in response to the warmer summer temperatures associated with higher insolation (Fig. 2).

After about 6,500 ${ }^{14} \mathrm{C}-\mathrm{yr} \mathrm{BP}$, the immigration and expansion of conifers (Pinus sylvestris, $P$. peuce, $P$. mugo, and Abies alba) to higher elevations depressed the temperate forest to elevations below 1,000 m. Beech and spruce subsequently expanded after ca. 3,000 ${ }^{14} \mathrm{C}$-yr BP. This late expansion of conifers in the Pirin Mountains is unexpected in view of the occurrence of pine macrofossils of glacial age in the nearby lowlands of Hungary (Willis et al., 2000). Clearly, long-distance migration cannot be invoked to explain the delayed immigration of conifers to the Pirin Mountains.
Rather, it is more likely that climatic conditions were unfavorable for high-elevation conifers until the late Holocene.

Although broad-leaved trees such as oak, elm, and linden reached elevations higher than present during the early Holocene, this apparently occurred in conjunction with a treeless zone that extended to elevations lower than today. The late expansion of the conifers, which are better adapted to high elevations than broad-leaved trees, shifted the deciduous forest down and the treeless zone up to their present ranges.

Dry early-Holocene climatic conditions in Eastern Europe may have been the cause for the unusual forest history in the Pirin Mountains. Along the Black Sea coast, eastern Bulgaria was dry enough for steppe to persist until the spread of deciduous forest about $8,000{ }^{14} \mathrm{C}$-yr BP. (Bozilova et al., 1996). Farther east in the Zagros Mountains of Iran, which are currently too dry for pine, the slow early-Holocene spread of oak and pistachio into grass steppe also implies dry climatic conditions.
This scenario is further supported by evidence from the Altai Mountains (below) in southern Siberia where the persistence of steppe vegetation until at least $9,000{ }^{14} \mathrm{C}$ yr BP and late afforestation by pine again provides an indication of dry early-Holocene conditions in the Eurasian mid-continent.

\section{Long-term vegetation dynamics in the Altai Mountains, Siberia}

The Altai Mountains are located in the centre of Eurasia where Russia, Khazakhstan, Mongolia and China meet. Sediment cores from an altitudinal transect of lakes on a high plateau south of Ulagan provide the opportunity to trace the vegetational history from late-glacial time to the present by pollen analysis of organic sediment. Earlier findings of abundant spruce and pine macrofossils at a site $200 \mathrm{~km}$ to the north and 1,000 $\mathrm{m}$ lower in elevation are dated to ca. $13,750{ }^{14} \mathrm{C}-\mathrm{yr}$ BP and indicate an area where a late-glacial refuge for these conifers may have existed.

Three lakes, at elevations ranging from 1,950 $\mathrm{m}$ in the upper for- 
est zone to 2,150 $\mathrm{m}$ at treeline, have very similar pollen records, well dated by radiocarbon analysis. Following a brief conifer zone in silt which may represent long-distance pollen transport to a barren landscape, the main sequence starts in organic sediment more than 13,000 ${ }^{14} \mathrm{C}$-yr ago with a steppe flora dominated by Artemisia, grasses, sedges, and chenopods, with spruce as a minor component (Fig. 3). Subdivision of the steppe phase into late-glacial interstadial and stadial intervals is not apparent. The persistence of steppe vegetation during the late-glacial (Tarasov, 2000; Chernova et al., 1991) may reflect the dominance of cold and dry northeasterly air flow from the Siberian anticyclone (Tarasov, 1997) which was strengthened by the supply of circum-polar arctic air north of the ice sheets on both continents. The dominance of steppe vegetation persisted until at least 9,000 ${ }^{14} \mathrm{C}$-yr BP, when increases in pollen of Siberian pine and Scots pine indicate broad afforestation.

Thus, not only was the late-glacial vegetational sequence in these interior mountains different from the observed sequence at sites closer to the Atlantic source of climatic change, but the ubiquitous expansion of forest seen in the Alps and other mountains and lowlands of Europe at the end of the late-glacial $\left(10,000{ }^{14} \mathrm{C}-\mathrm{yr}\right.$ BP) did not occur in the Altai until 1,000 years later (Fig. 3). The continuation of steppe conditions well into the Ho-

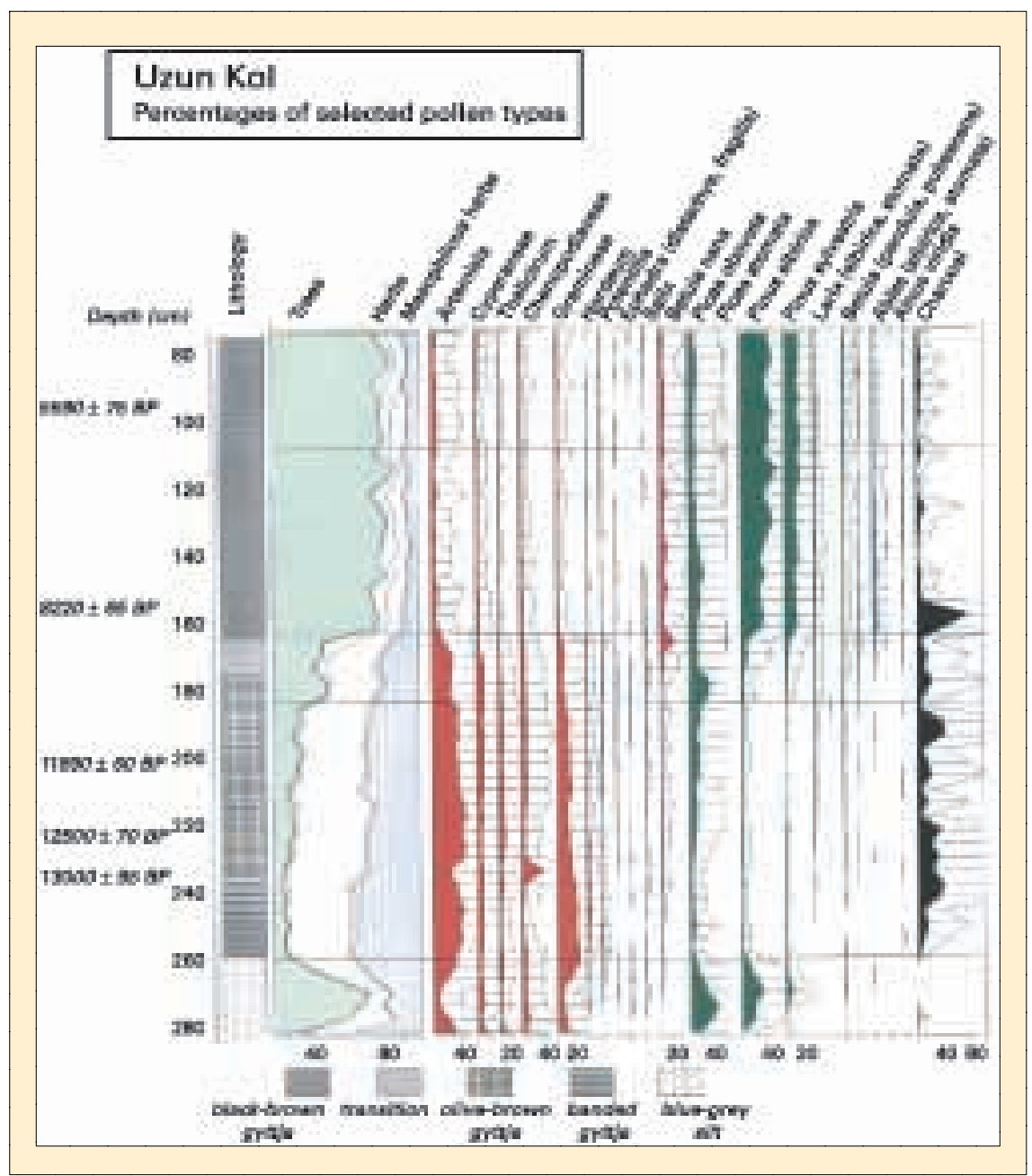

Fig. 3: Percentages of selected pollen taxa at Uzun Kol, Altai, Siberia, at 1,985 m asl. The basal zone in the silt is poor in pollen and is dominated by tree pollen (3 origins are possible: long-distance transported, reworked, or original from refugial habitats for trees). The period of the banded gyttja and the olive-brown gyttja (Late-Glacial and Early Holocene up to about 9,500 radiocarbon yrs BP) is dominated by steppe vegetation. After a transition zone of about 1,000 years the local conifers expanded: Pinus sibirica and Larix sibirica near the lake Uzun, Scots Pine, spruce and even the demanding fir at lower elevations in the Ulagan Valley locene can be attributed to warm, dry summers related to the insolation maximum. Unfortunately, cold late-glacial steppe vegetation cannot easily be distinguished from warm Holocene steppe by palynological analysis.

These findings provide support for paleoclimatic model simulations that reconstruct cold and dry conditions maintained by northeasterly winds at $12,000{ }^{14} \mathrm{C}$-yr BP and summer temperatures $2-4^{\circ} \mathrm{C}$ higher than present at 9,000 ${ }^{14} \mathrm{C}$-yr BP in southern Siberia (COHMAP members 1988).

This temporal sequence of steppe, persisting in the Altai Mountains from the late-glacial into the early Holocene, resembles the biogeographic sequence across the region today. Forests in the more humid west grade into steppe vegetation in the east, where trees are restricted to patches on northfacing slopes. The pollen stratigraphy of sediments recovered from mountain lakes in the eastern dry region, now the focus of a continuing study, will address the question whether or not steppe vegetation was present throughout the Holocene, despite long-term changes in summer insolation.

\section{REFERENCES}

Bozilova, E., Filipova, M., Filipovich, L. and Tonkov, S., 1996, Bulgaria. In Berglund, B.E., Birks, H.J.B., Ralska-Jasiewiczowa, M. and Wright, H.E. editors, Paleoecological Events During the Last 15000 Years: Regional Syntheses of Paleoecological Studies of Lakes and Mires in Europe, Chichester: John Wiley and SonsLtd, 701-728.

Chernova, G.M., Mikhailov, N.N., Denisenko, V.P., Kosyreva, M.G. 1991, Some questions of paleogeography of Holocene of southeastern Altai (in Russian). Izvestiya vsesoyuznogo geograficheskogo obshestva, Vyp 2., 140-146

Tarasov, P.E., Jolly D., Kaplan J.O. 1997, A continuous Late Glacial and Holocene record of vegetation changes in Kazakhstan. Palaeugeography, Paleoclimatology, Paleoecology 136: 281-292.

Stefanova, I. 1997, New data on the Late Holocene vegetative succession in the Northern Pirin Mts.: pollen and macrofossil analysis of depositions from peat bogs Goce Delchev and Visokata Ela.Phytologia Balcanica, 3/2-3.

Stefanova, I. and Ammann, B., in press, Late Glacial and Holocene vegetation belts in the Pirin Mountains (southwestern Bulgaria. The Holocene

For full references please consult:

www.pages-igbp.org/products/newsletter/ref20013.html 